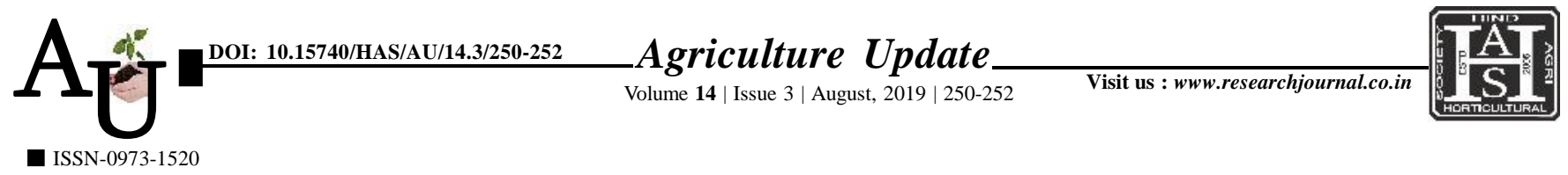

\title{
Rевевсн автіск: Assessing the knowledge level of ethno- agriculture practices in paddy among the tribal farmers of \\ Article Chronicle : Kalrayan hills
}

Received :

19.06.2019;

Revised :

17.07.2019;

Accepted :

27.07.2019

\section{KEY WoRDS :}

Ethno agricultural practices, Knowledge level of paddy, Tribal farmers

\section{Karnaraja and M. Natarajan}

SUMMARY : In recent century the tribal people had huge type of knowledge that possesses and employ orient is an important in agricultural sector, yet often the various type of element in the research information of traditional agriculture was documented for the sustainable agriculture. This information was extremely different, ranging from detailed knowledge of specific plants growth in cultivating broader sector of categorization that how better to particular cultural group views. The peoples inhabit and how this may use to shape the cultivation practices were coping up with the environment was most important in recent decades of agricultural cultivation practices. Indigenous agricultural practices are the progenitor's knowledge of the tribal community that has passed from one decade to another decade to be followed by generation to generation. This paper deals with the various indigenous agricultural practices adopted by the tribal farmers of Kalvarayan hills in Villupuram district of Tamil Nadu. The 300 tribal respondents were selected by the proportionate random sampling method with ten revenue villages in the Kalrayan hills. The practices has been sent to the various SAU, principle scientist and research experts to identify the Ethno agricultural practices in paddy and the data were analysed by appropriate statistical methods. The study concluded that majority of tribal respondents had high level of knowledge in different Ethno agricultural practices of paddy (Venkatesan et al., 2016) and Lakra et al., 2010).

How to cite this article : Karnaraja, D. and Natarajan, M. (2019). Assessing the knowledge level of ethnoagriculture practices in paddy among the tribal farmers of kalrayan hills. Agric. Update, 14(3): 250-252; DOI : 10.15740/HAS/AU/14.3/250-252. Copyright@ 2019: Hind Agri-Horticultural Society.
Author for correspondence :

\section{Karnaraja}

Department of

Agricultural Extension,

Annamalai University,

Annamalai Nagar

(T.N.) India

Email:tmthatchupeaceful

@ gmail.com

See end of the article for

authors' affiliations 